\title{
Holocene productivity changes off Adélie Land (East Antarctica)
}

\author{
Delphine Denis, ${ }^{1}$ Xavier Crosta, ${ }^{1}$ Sabine Schmidt, ${ }^{1}$ Damien S. Carson, ${ }^{2}$ \\ Raja S. Ganeshram, ${ }^{2}$ Hans Renssen, ${ }^{3}$ Julien Crespin, ${ }^{4}$ Olivier Ther, ${ }^{1}$ Isabelle Billy, ${ }^{1}$ \\ and Jacques Giraudeau ${ }^{1}$ \\ Received 21 September 2008; revised 17 February 2009; accepted 29 May 2009; published 28 August 2009.
}

[1] This study presents the first high-resolution multiproxy investigation of primary productivity (PP) during the Holocene from the Antarctic continental margins. Micropaleontological and geochemical data from the sediment core MD03-2601, associated to sea ice model outputs, give unprecedented insights into the biological pump of the Antarctic coastal area off Adélie Land in response to climatic changes. Plurimillennial and millennial changes of PP are observed in the study area in response to changes in nutrient availability, stratification, and growing season duration, which are linked to sea ice, upwelling, wind, and glacier dynamics. The precessional cycle seems to be responsible in the PP long-term variations, while forcing factors involved at the millennial timescale remain more enigmatic. Our results emphasize enhanced biological pump during warmer and windier Holocene phases because of a longer growing season and greater nutrient input. Antarctic coastal and continental shelf zones may therefore represent a more intense carbon sink in the future.

Citation: Denis, D., X. Crosta, S. Schmidt, D. S. Carson, R. S. Ganeshram, H. Renssen, J. Crespin, O. Ther, I. Billy, and J. Giraudeau (2009), Holocene productivity changes off Adélie Land (East Antarctica), Paleoceanography, 24, PA3207, doi:10.1029/2008PA001689.

\section{Introduction}

[2] Coastal and continental shelf zones (CCSZ) are among the most productive ecological provinces of the Southern Ocean which account for ca. $76 \%$ and 3.5\% of the total primary productivity (PP) of the marginal ice zone (MIZ) and Southern Ocean, respectively [Smith and Gordon, 1997; Arrigo et al., 2008]. Enhanced PP levels in ice edge zones are commonly related to a combination of nutrient enrichment, seasonal stratification of the surface ocean by ice melting, and growing season duration [Smith and Nelson, 1985; Leventer, 1992; Arrigo and van Dijken, 2003; Arrigo et al., 2008]. Enhanced seasonality in CCSZ, which favors a high export/production ratio, subsequently induces higher accumulation and burial of organic matter in the underlying sediment [Berger and Wefer, 1990; Buesseler, 1998]. Therefore, the Antarctic sea ice zones are significantly involved in the global carbon biological pump (i.e., the amount of carbon removed from the atmosphere and permanently buried in the sediment) and related atmospheric pCO2 modulations [Longhurst and Harrison, 1989; Nelson et al., 1995].

[3] Currently, the response of PP and resultant global carbon cycle in sea ice zones to global warming remains unclear and controversial [Arrigo et al., 1999; Collier et al.,

\footnotetext{
${ }^{1}$ EPOC, UMR 5805, Université Bordeaux 1, CNRS, Talence, France.

${ }^{2}$ Grant Institute, School of GeoSciences, University of Edinburgh, Edinburgh, UK

${ }^{3}$ Faculty of Earth and Life Sciences, Vrije Universiteit Amsterdam, Amsterdam, Netherlands.

${ }^{4}$ CEREGE, UMR 6635, CNRS, Aix-en-Provence, France.
}

Copyright 2009 by the American Geophysical Union. 0883-8305/09/2008PA001689
2000; Arrigo and Thomas, 2004; Tortell et al., 2008; Arrigo et al., 2008]. However, model studies predict that the ongoing climate change will induce enhanced Southern Ocean upwelling of nutrient rich waters [Toggweiler et al., 2006; Russell et al., 2006], reduced iron availability [Kattenberg et al., 1996; Sarmiento et al., 1998], and retreat of sea ice extent [Goosse and Renssen, 2001; Lefebvre and Goosse, 2008]. These parameters are important in controlling PP levels via the modulation of the nutrient supply, stratification and growing season duration.

[4] Given the debate surrounding the impact of climate change on PP in the CCSZ, we have investigated the response of PP to glacier, oceanic, atmospheric, and sea ice changes in a Holocene sediment archive from the CCSZ off Adélie Land, East Antarctica. Records of opal and organic carbon vertical fluxes, which are robust tracers of the biological pump efficiency in the CCSZ [Carson, 2009], are compared to new records of ${ }^{230} \mathrm{Th}$-normalized iron and organic nitrogen fluxes, nitrogen stable isotopic ratio, diatom assemblages and sea ice cover model transient simulations for the Holocene period. This new data set allows us (1) to constrain Holocene variations of buried paleoproductivity, (2) to identify the main controlling factors of past PP variations, (3) to better understand the impact of past climatic conditions (sea ice, upwelling, wind, temperature, glacier) on PP controlling factors in order to (4) construct a comprehensive picture of the biological pump changes throughout the last $11 \mathrm{ka}$. Interpretations drawn for the Holocene period can be used to infer future PP in warming climate.

\section{Environmental and Biological Settings}

[5] The Dumont d'Urville Trough (DDUT), which comprises many glacial depressions, is located off Adélie Land 


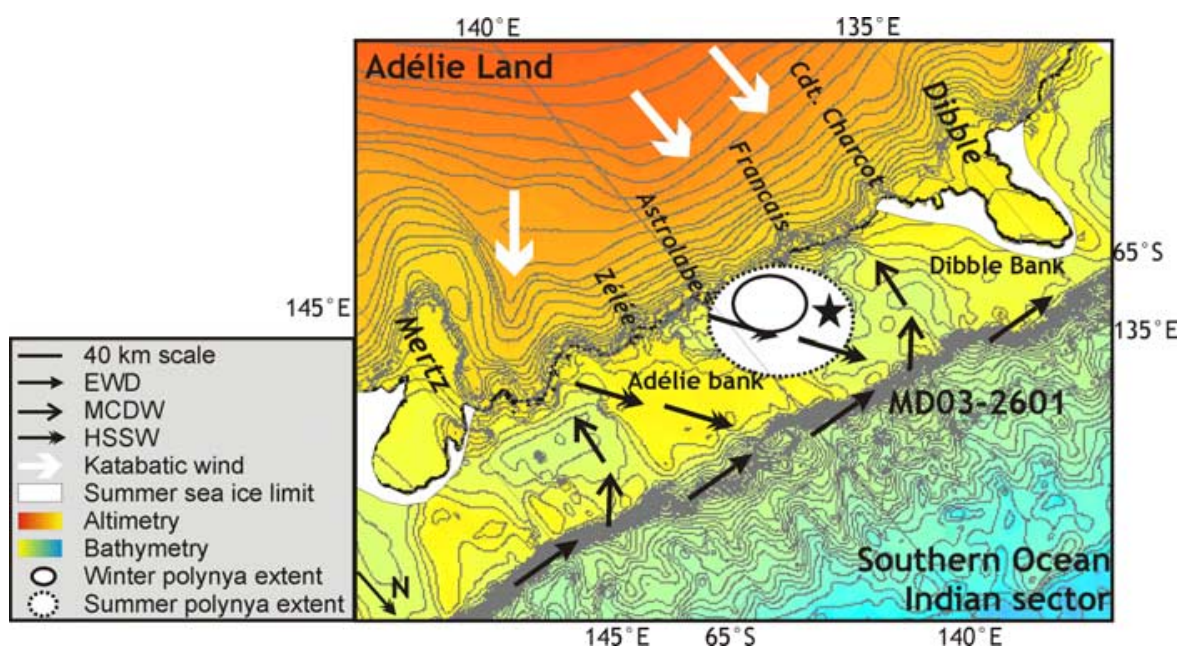

Figure 1. Map of the study area (modified after Denis et al. [2009]), showing the location of sediment core MD03-2601, altimetry and bathymetry, locations of glaciers (in italic), limit of summer sea ice cover [Schweitzer, 1995], detail of oceanographic currents and different water masses [Rintoul, 1998; Harris and Beaman, 2003; Williams and Bindoff, 2003], katabatic wind directions [Massom et al., 1998], and the average winter and summer extent of the DDUT polynya [Arrigo and van Dijken, 2003]. Winter sea ice covers the whole oceanic area encompassed by the map. EWD, East Wind Drift; MCDW, Modified Circumpolar Deep Water; HSSW, high-salinity shelf water. Bathymetry data are based on ETOPO2 data set from http://www.ngdc.noaa.gov/mgg/fliers/01mgg04.html.

on the East Antarctica margin (Figure 1). These depressions act as sediment traps, which focus the phytoplankton detritus produced in the area, increasing their preservation potential.

[6] The DDUT region is influenced by several water masses and currents [Rintoul, 1998; Bindoff et al., 2000a, 2000b; Williams and Bindoff, 2003]: (1) the wind-driven East Wind Drift (EWD), also called Antarctic Coastal Current, which flows westward at the surface; (2) the Antarctic Surface water (AASW) constituting the summer near-surface water mass on the continental shelf; (3) the Modified Circumpolar Deep Water (MCDW) which upwells at the Antarctic Divergence; and (4) the high-salinity shelf water (HSSW), formed by brine rejection during winter sea ice formation and cooling of the MCDW (Figure 1), which flows northward as part of the Adélie Land Bottom Water (ALBW).

[7] The CCSZ is supplied with macronutrients and micronutrients from several sources such as upwelling of MCDW [Coale et al., 2005], resuspension of shelf sediments [Sedwick et al., 2000], aeolian input [Cassar et al., 2007], and melting of glacial ice and sea ice [Edwards and Sedwick, 2001; Lannuzel et al., 2007]. In the CCSZ, macronutrients are generally not exhausted at the end of the growing season [Strutton et al., 2000] whereas trace metals such as iron (Fe) can become a limiting factor for annual PP [Arrigo et al., 2003; Smetacek and Nicol, 2005].

[8] The coastal area off Adélie Land is presently exposed to strong katabatic winds [Périard and Pettré, 1993] that support the Dumont d'Urville polynya, located southward at $66.11^{\circ} \mathrm{S}-139.31^{\circ} \mathrm{E}$, throughout the winter season [Adolphs and Wendler, 1995; Arrigo and van Dijken, 2003] (Figure 1). The DDUT area is totally ice-free or under the influence of the Dumont d'Urville postpolynya (e.g., the winter polynya that extends into the spring-summer season) from late spring to late summer [Schweitzer, 1995; Arrigo and van Dijken, 2003]. The ice-free conditions last between 3 and 5 months (e.g., between November-December and February-March), and hence give a good estimation of the length of the phytoplanktonic growing season in the DDUT area (Figure 1).

[9] Primary productivity in surface waters of the DDUT is around $4.6 \mathrm{molC} / \mathrm{m}^{2} / \mathrm{a}$, which is on the lower side of the range of PP estimates in CCSZ, between 1 and $13 \mathrm{molC} /$ $\mathrm{m}^{2}$ /a [Nelson et al., 1996; Arrigo and van Dijken, 2003; Beucher et al., 2004; Beans et al., 2008]. The only data set available on PP preserved in the CCSZ sediment shows values around $0.02 \mathrm{molC} / \mathrm{m}^{2} / \mathrm{a}$ (values are not ${ }^{230} \mathrm{Th}$ normalized) in the Ross Sea [Nelson et al., 1996], which is among the most productive CCSZ areas [Arrigo and van Dijken, 2003]. PP is initiated in spring when light availability and stratification are favored by sea ice waning, whereas decreasing PP at the end of the summer-autumn season likely results from trace metal limitation and grazing pressure [Smetacek et al., 2004]. The algal community is mainly controlled by surface water stratification, which depends on temperature, wind stress, sea ice and glacial runoff [Wright and van den Enden, 2000]. Diatoms blooms are favored by injection of freshwater that produces a stratified stable environment [Leventer, 1992] and are dominant in the Adélie Land region at present time [Wright and van den Enden, 2000].

\section{Material and Methods}

\subsection{Core Description}

[10] Piston core MD03-2601 (66 $03.07^{\prime} \mathrm{S}$; $138^{\circ} 33.43^{\prime} \mathrm{E}$; $746 \mathrm{~m}$ water depth) was recovered from the slope of one of 
the depressions comprising the DDUT (Figure 1) in 2003 during the CADO cruise (MD130 Images Coring Adélie Diatom Oozes) on board the R/V Marion Dufresne II. The age model used here, detailed in the work by Denis et al. [2009], is based on 7 radiocarbon dates (depths shown in Figure 2) completed on the humic fraction of bulk organic matter, corrected with a 1300 years age reservoir [Ingólfsson et al., 1998], calibrated using CALIB 5.0 software (M. Stuiver et al., 2005; available at http://radiocarbon.pa. qub.ac.uk/calib/) and the marine calibration Marine04 [Hughen et al., 2004]. The 40-m-long sediment core covers the $1-11 \mathrm{cal}$ ka B.P. period with a mean accumulation rate of $0.4 \mathrm{~cm} / \mathrm{a}$ and shows submillimetric to centrimetric seasonal laminations [Denis et al., 2006, 2009].

\subsection{Geochemical Data}

[11] Downcore iron $(\mathrm{Fe})$ measurements were performed every $32 \mathrm{~cm}(\sim 80$ years resolution) by X-ray fluorescence (XRF) analysis, optimized for major elements. Complete XRF methodology is described by Fitton et al. [1998]. Standard deviations of $\mathrm{Fe}$ measures are 0.03. Iron content has been ${ }^{230} \mathrm{Th}$ normalized from high-resolution ${ }^{230} \mathrm{Th}$ measurements $(\mathrm{n}=60$ [Denis et al., 2009]) following the Francois et al. [2004] calculation, yielding to a 170 year resolution (see method details in the work by Carson [2009]). The ${ }^{230}$ Th-normalized Fe fluxes present a mean $\sigma$ error of $24 \%(p>0.05)$ by addition of the errors associated to the ${ }^{14} \mathrm{C}$ age, thorium and uranium extraction and treatment, DBD calculation and Fe determination (see error bars in Figure 2e). The ${ }^{230} \mathrm{Th}$ normalization permits to circumvent problems of lateral focusing and sediment component changes, and therefore allows accurate reconstructions of the vertical flux [Francois et al., 2004].

[12] Nitrogen isotopic measurements $\left(\delta^{15} \mathrm{~N}_{\text {bulk }}\right)$ and organic nitrogen content $\left(\mathrm{N}_{\text {org }}\right)$ on bulk organic matter were undertaken every $4 \mathrm{~cm}$ to $8 \mathrm{~cm}(\sim 10-20$ years resolution) on a Carlo Erba 2500 elemental analyzer in line with a VG Isoprime, following the method described by Crosta et al. [2005a]. The mean standard deviation is $0.25 \%$ for the $\delta^{15} \mathrm{~N}_{\text {bulk }}$ and $0.01 \%$ for the $\mathrm{N}_{\text {org. }}$. Organic nitrogen content (\%) has been ${ }^{230} \mathrm{Th}$ normalized as explained for $\mathrm{Fe}$ in order to reconstruct the preserved vertical flux of nitrogen at a 170 years resolution (mean $\sigma$ error $=24 \%$ for $p>0.05$, see error bars in Figure 2a).

\subsection{Micropaleontological Data}

[13] Diatom census counts, followed Schrader and Gersonde [1978] and Laws [1983] were performed every 4-8 cm at the same depth than $\mathrm{C}_{\text {org }}$ and $\mathrm{N}_{\text {org }}$ samples, presenting a $\sim 10-20$ years resolution. More details about slide preparation and diatom identification are found in the work by Crosta et al. [2004]. Around 350 diatom valves were counted in each sample and the relative abundance of each was determined as the fraction of diatom species against total diatom abundance in the sample.

[14] The relative abundances of some diatom species have been summed according to their relative similar ecological preferences. Fragilariopsis kerguelensis and F. rhombica, which have been both previously published by Crosta et al. [2005a, 2008] are summed with F. ritcherii, F. separanda, Pseudonitzschia spp., Thalassiosira tumida, Thalassiothrix spp. and Thrichotoxon reinboldii in the summer diatom group. Studies of diatom distribution in surface sediments and in laminated fossil sediments have shown that these species grow during the summer season with ice-free conditions [Armand et al., 2005; Crosta et al., 2005b; Maddison et al., 2005, 2006; Stickley et al., 2005; Denis et al., 2006; Timmermans et al., 2008].

[15] Chaetoceros Phaeoceros spp. (dominated by C. dichaeta), Corethron pennatum, Rhizosolenia spp. and Proboscia spp. have been summed in the setae diatom group. Several studies have identified these species during spring [Denis et al., 2006; Maddison et al., 2006] and/or summer and fall seasons [Leventer et al., 2002], in neritic and/or more oceanic waters [Armand et al., 2005; Crosta et al., 2005b], in well-stratified [Leventer et al., 2002] and/or mixed water column [Beans et al., 2008], and in oligotrophic [Stickley et al., 2005] and/or nutrient-rich surface waters [Beans et al., 2008]. Nonetheless, in Adélie Land region, Beans et al. [2008] associated clearly the species of the setae diatom group with nutrient-rich and mixed surface waters.

[16] Finally, we use the Chaetoceros Hyalochaete spp. resting spore (CRS) relative abundances, which the 9-1 cal ka B.P. part of the MD03-2601 record have been previously published by Crosta et al. [2005a, 2008]. Resting spore formation of Chaetoceros Hyalochaete spp. are mainly associated to surface waters depleted in nutrient after intense spring blooms, which have been promoted in well-stratified nutrient-rich water column [Leventer, 1991, 1992; Crosta et al., 1997; Leventer et al., 2002].

\subsection{Model Simulations}

[17] Variations of annual sea ice cover was extracted between $130-150^{\circ} \mathrm{E}$ and $64-70^{\circ} \mathrm{S}$ from a 9000 -year-long transient experiment simulated with the ECBilt-CLIOVECODE coupled atmosphere-sea ice-ocean-vegetation model [Renssen et al., 2005]. This experiment was forced by millennial-scale forcings, i.e., variations in orbital parameters and atmospheric greenhouse gas levels. Using the simulated sea ice cover, the number of months per year with ice-free conditions was determined according to Arrigo and van Dijken [2003], i.e., considering a mean sea ice cover of less than $50 \%$. At the end of the experiment (e.g., 200 years B.P.), yearly ice-free duration are slightly lower than those reported by Arrigo and van Dijken [2003] on the 1997-2002 period (3 instead of 4 months per year). This underestimation of ice-free duration in the model is possibly due to the nonrepresentation of the DDU polynya and postpolynya, which favor earlier ice-free conditions. It is worth noting that the model outputs can be examined over the Milankovitch timescale and not at the sub-Milankovitch one, as external forcings important at the latter timescale (such as variations in solar irradiance and volcanic aerosol content of the atmosphere) were not considered in the experiment of Renssen et al. [2005].

\section{Results}

[18] Our results are presented and described concomitantly to ${ }^{230}$ Th-normalized $\mathrm{BSi}$ and $\mathrm{C}_{\text {org }}$ fluxes, which have been previously presented by Carson [2009]. 


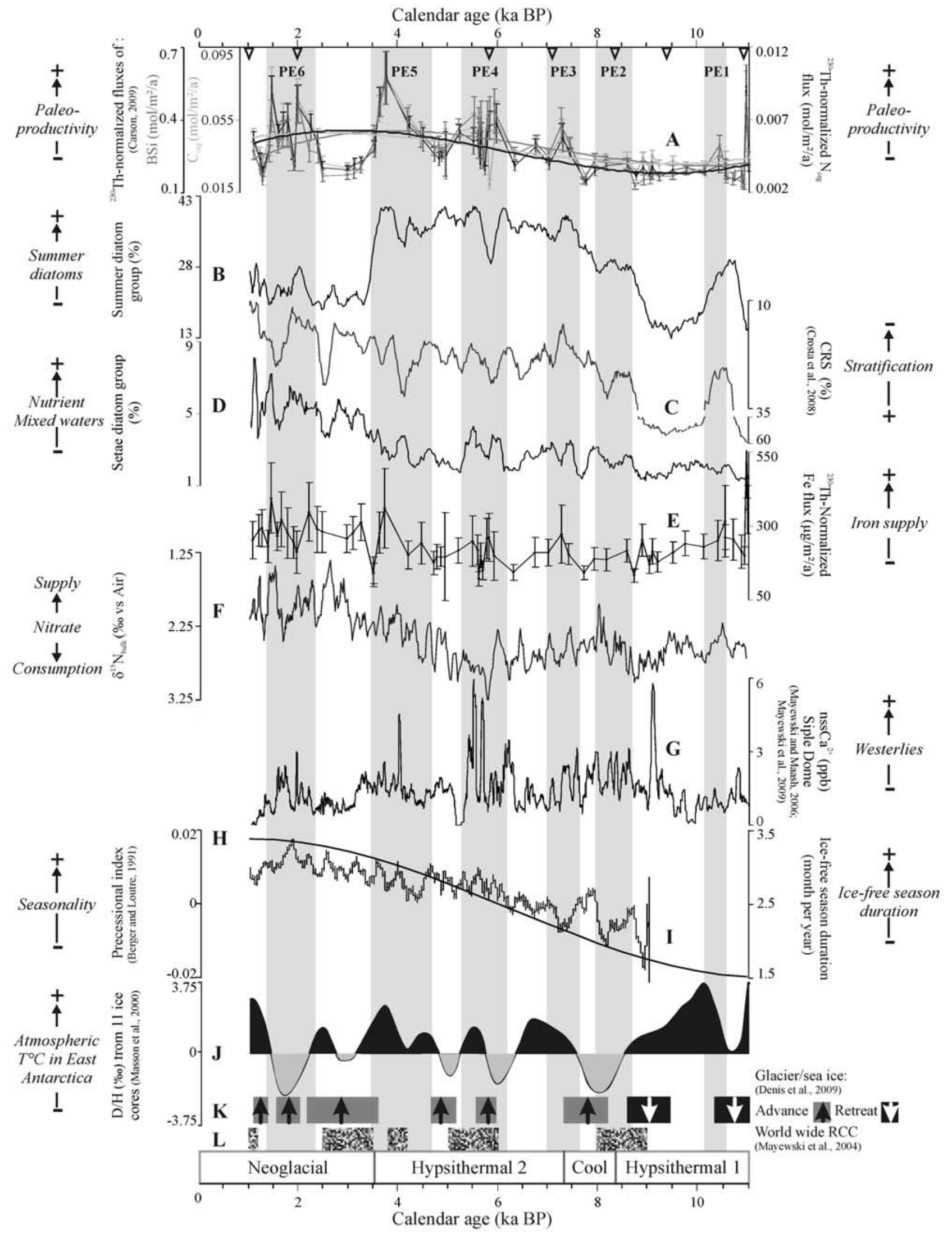

Figure 2 
Table 1. Kendall's tau correlation coefficients ${ }^{\mathrm{a}}$

\begin{tabular}{|c|c|c|c|c|c|c|c|c|c|c|c|}
\hline & ${ }^{230} \mathrm{Th}-\mathrm{BSi}$ & ${ }^{230} \mathrm{Th}-\mathrm{C}_{\mathrm{org}}$ & ${ }^{230} \mathrm{Th}-\mathrm{N}_{\mathrm{org}}$ & $\mathrm{Fe}$ & Summer Group & CRS & Setae Group & $\delta^{15} \mathrm{~N}_{\text {bulk }}$ & $\mathrm{n}$ & $\sigma=\mathrm{p}>0.001$ & $\sigma=\mathrm{p}>0.1$ \\
\hline${ }^{230} \mathrm{Th}-\mathrm{BSi}$ & & $1.5 \mathrm{E}-15$ & $4.4 \mathrm{E}-18$ & $2.1 E-01$ & $7.5 \mathrm{E}-06$ & $9.0 E-03$ & $8.0 E-03$ & $8.4 E-01$ & 60 & $1.7 \mathrm{E}-05$ & $1.8 \mathrm{E}-03$ \\
\hline${ }^{230} \mathrm{Th}-\mathrm{C}_{\mathrm{org}}$ & 0.707 & & $2.1 \mathrm{E}-20$ & $2.6 E-02$ & $8.0 E-03$ & $5.0 E-03$ & 4.0E-03 & $1.3 E-01$ & 60 & $1.7 \mathrm{E}-05$ & $1.8 \mathrm{E}-03$ \\
\hline${ }^{230} \mathrm{Th}-\mathrm{N}_{\mathrm{org}}$ & 0.768 & 0.820 & & $5.7 E-03$ & $4.1 E-03$ & $1.2 \mathrm{E}-03$ & $8.0 \mathrm{E}-04$ & $1.8 E-01$ & 60 & $1.7 \mathrm{E}-05$ & $1.8 \mathrm{E}-03$ \\
\hline $\mathrm{Fe}$ & 0.111 & 0.197 & 0.245 & & $1.8 E-02$ & $2.2 E-01$ & $1.5 E-01$ & $1.0 \mathrm{E}-03$ & 60 & $1.7 \mathrm{E}-05$ & $1.8 \mathrm{E}-03$ \\
\hline Summer Group & 0.397 & 0.236 & 0.254 & -0.210 & & $3.6 \mathrm{E}-10$ & $5.0 E-02$ & $1.1 \mathrm{E}-12$ & 528 & $1.9 \mathrm{E}-06$ & $2.0 \mathrm{E}-04$ \\
\hline CRS & -0.229 & -0.246 & -0.287 & -0.109 & -0.183 & & $2.7 \mathrm{E}-80$ & $5.4 \mathrm{E}-34$ & 528 & $1.9 \mathrm{E}-06$ & $2.0 \mathrm{E}-04$ \\
\hline Setae Group & -0.232 & -0.258 & -0.297 & -0.127 & -0.050 & -0.552 & & 3.7E-59 & 528 & $1.9 \mathrm{E}-06$ & $2.0 \mathrm{E}-04$ \\
\hline$\delta^{15} \mathrm{~N}_{\mathrm{bulk}}$ & 0.018 & -0.135 & -0.119 & -0.303 & 0.207 & 0.354 & -0.472 & & 528 & $1.9 \mathrm{E}-06$ & $2.0 \mathrm{E}-04$ \\
\hline
\end{tabular}

${ }^{\mathrm{a}}$ Correlation coefficients are reported in the bottom left side, and significance values ( $\mathrm{p}$ values) are reported in the top right side (bold and normal fonts represent $p>0.001$ and $p>0.1$, respectively, and italic font represents the nonsignificant values). The test is significant if its associated probability ( $p$ value) is smaller than the level of confidence $\sigma$. Here we used the Šidák-Bonferonni correction, which takes into account the number of samples considered (n), to determine the $\sigma$ required following the equation $\sigma_{\text {required }}=1-(1-\sigma)^{1 / n}$, where $\sigma$ is the $\mathrm{p}$ value chosen and $\mathrm{n}$ is the number of samples considered [Abdi, 2007]. Number of samples and $\sigma$ required to have significant correlation at $\mathrm{p}>0.001$ and $\mathrm{p}>0.1$ are reported in the last three columns. The Kendall's tau correlation coefficient calculations have been calculated using the free software PAST 1.75 (Ø. Hammer et al., 2007; available at http://folk.uio.no/ ohammer/past). This test has been performed on ${ }^{230} \mathrm{Th}$-normalized fluxes of $\mathrm{BSi}, \mathrm{C}_{\text {org }}, \mathrm{N}_{\text {org }}$, and Fe on diatom relative abundances and on $\delta^{15} \mathrm{~N}_{\text {bulk }}$ values. Diatom relative abundances and $\delta^{15} \mathrm{~N}_{\text {bulk }}$ are particularly sensitive to seasonal variability. We therefore smoothed their high-resolution records to reduce the seasonal noise possibly captured in the stepwise sampling of the laminated MD03-2601 core. Given the laminated structure of the core, it appears hazardous to calculate correlation coefficients between records having different resolutions. We therefore calculated the Kendall's tau correlation coefficient between two records at the highest common resolution.

[19] The 3-order polynomial functions applied to ${ }^{230} \mathrm{Th}$ normalized fluxes of $\mathrm{N}_{\text {org }}, \mathrm{C}_{\text {org }}$ and $\mathrm{BSi}$ show similar trends during the Holocene with relatively low values between 11 and $9 \mathrm{cal}$ ka B.P., a long-term increase between 9 and $3 \mathrm{cal}$ ka B.P. and a slight decrease after 3 cal ka B.P. (Figure 2a). Between 9 and 3 cal ka B.P., the ${ }^{230}$ Th-normalized fluxes of $\mathrm{N}_{\text {org }}, \mathrm{C}_{\text {org }}$ and $\mathrm{BSi}$ show a 1.5 -fold increase from 0.004 to $0.006 \mathrm{molN} / \mathrm{m}^{2} / \mathrm{a}, 0.03$ to $0.05 \mathrm{molC} / \mathrm{m}^{2} / \mathrm{a}$ and 0.2 to $0.3 \mathrm{molSiO}_{2} / \mathrm{m}^{2} / \mathrm{a}$ (Figure 2a). On the basis of the general trend, highest $\mathrm{C}_{\text {org }}$ and $\mathrm{N}_{\text {org }}$ fluxes occurred between 5 and 1 cal ka B.P. while highest flux of BSi occurred between 6 and 2 ka B.P. (Figure 2a). The Holocene general trend is punctuated by several increases of the ${ }^{230} \mathrm{Th}$-normalized fluxes of $\mathrm{N}_{\text {org }}, \mathrm{C}_{\text {org }}$ and $\mathrm{BSi}$ at around 10.6-10.2, 8.7-8, 7.6-7, 6.2-5.3, 4.6-3.5, and 2.4-1.4 cal ka B.P. and noted hereafter P1 to P6, respectively (Figure 2a). We note that the amplitude and the duration of the PE follow the Holocene pattern with an increase from PE1 to PE5 and a decrease since PE5. The amplitude increased by 1.5 to 2.5 fold while the duration increased from 500 to $1000-1200$ years between the early and the late Holocene, respectively
(Figure 2a). The ${ }^{230}$ Th-normalized biogenic fluxes are significantly correlated together (Table 1).

[20] The summer diatom group accounts for 13 to $40 \%$ of the diatom assemblages. It is the more abundant diatom group between 9 and $3.5 \mathrm{cal}$ ka B.P., representing more than one third of the diatom assemblage during this period (Figure $2 b$ ). The summer diatom group shows a long-term increase between 9 and 3.5 cal ka B.P., subsequently followed by a pronounced decrease (Figure 2b). Millennial events of increasing occurrence at around 10.6-10.2, 8.7$8,7.6-7,6.2-5.3,5.1-4.9,4.6-3.5,2.4-2$ and $1.5-1 \mathrm{cal}$ ka B.P. are superimposed to the Holocene trend (Figure 2b). The summer diatom group record is significantly correlated with ${ }^{230}$ Th-normalized BSi flux (Table 1). The summer diatom group record also shows positive correlations with ${ }^{230}$ Th-normalized $\mathrm{C}_{\text {org }}$ and $\mathrm{N}_{\text {org }}$ fluxes though the test of significance is just below the threshold (Table 1).

[21] CRS relative abundances show a long-term decrease from 60 to $10 \%$ between 11 and 1 cal ka B.P. [Crosta et al., 2008] (Figure 2c). This general trend is interrupted by several drops at around $10.6-10.2,8.7-8.3,7.6-7,6.4-$

Figure 2. Micropaleontological, geochemical, and isotopic records in core MD03-2601 versus time compared to records of Antarctic climate. Marine, ice core, and model records are presented on independent timescales. (a) The ${ }^{230} \mathrm{Th}$ normalized fluxes of $\mathrm{N}_{\text {org }}$ (black line), BSi (dark gray line), and $\mathrm{C}_{\text {org }}$ (light gray line) from Carson [2009] (error bars represent the confident interval at $\mathrm{p}>0.05$ ) and their plurimillennial trends, emphasized by a 3-order polynomial function. (b) Relative abundances of the summer diatom group (10-point running average). (c) Relative abundances of Chaetoceros Hyalochaete spp. resting spores (CRS) (10-point running average; note the reversed $y$ axis) [Crosta et al., 2008]. (d) Relative abundances of the setae diatom group (10-point running average). (e) The ${ }^{230}$ Th-normalized iron flux (error bars represent the confident interval at $\mathrm{p}>0.05)$. (f) Nitrogen stable isotope ratio in bulk sediments $\left(\delta^{15} \mathrm{~N}_{\text {bulk }}\right)(10$-point running average; note the reversed $y$ axis). (g) Non-sea salt $\mathrm{Ca}^{2+}$ content in Siple Dome ice core [Mayewski and Maasch, 2006; Mayewski et al., 2009; P. Mayewski, personal communication, 2008] (10-point running average). (h) Orbital precessional index [Berger and Loutre, 1991]. (i) Duration of the ice-free season modeled for the study area $\left(130^{\circ}-140^{\circ} \mathrm{E}\right.$, south of $\left.64^{\circ} \mathrm{S}\right)(200$-point running average). (j) Empirical orthogonal function of deuterium isotopic ratio records in 11 ice cores from East Antarctica [Masson et al., 2000]. (k) Periods of glacier/sea ice advance and retreat reported from Denis et al. [2009]. (1) Worldwide rapid climatic changes (RCC) presented by Mayewski et al. [2004] stacked from 50 Holocene paleoclimatic records. At the top, triangles represent the positions of the ${ }^{14} \mathrm{C}$ dates used in the age model [Denis et al., 2009], and at the bottom, the climatic periods of the Holocene are defined from Crosta et al. [2005a]. Gray shaded areas highlight millennial increases of paleoproductivity called PE1 to PE6, which are reported at the top of the plot. 
6, 5.6-5.3, 4.7-4.4, 4-2.6, 2.4-2 and 1.4-1 cal ka B.P. (Figure 2c). CRS relative abundances are significantly anticorrelated along the Holocene with relative abundances of the summer diatom group and ${ }^{230}$ Th-normalized $\mathrm{N}_{\text {org }}$ flux. CRS abundances also display negative correlations with ${ }^{230}$ Th-normalized fluxes of $\mathrm{BSi}$ and $\mathrm{C}_{\text {org }}$ though the test of significance is just below the threshold (Table 1).

[22] The setae diatom group reaches 1 to $8 \%$ of the diatom abundances along the Holocene with relatively low percentages around $2 \%$ in the first part of the Holocene and a steady increase since 5 cal ka B.P. to reach around $6 \%$ at the core top (Figure 2d). This general trend is punctuated by several peaks of higher relative abundances at around 8.7-8, 7.6-7, 6.2-5.3, 4.1-3.9, 3.4-2.6, 2.4-1.6 and 1.5-1 cal ka B.P. (Figure 2d). The setae diatom group record shows strong negative correlations with CRS relative abundances and ${ }^{230}$ Th-normalized $\mathrm{N}_{\text {org }}$ flux and negative but nonsignificant correlations with ${ }^{230}$ Th-normalized fluxes of $\mathrm{BSi}$ and $\mathrm{C}_{\text {org }}$ (Table 1).

[23] The ${ }^{230}$ Th-normalized flux of iron varies between 130 and $580 \mu \mathrm{g} / \mathrm{m}^{2} / \mathrm{a}$ along the Holocene. This record displays a relatively similar evolution than the setae diatom group record with a linear trend between 11 and 5 cal ka B.P. and a steady increase between 5 and 1 cal ka B.P. (Figure 2e) though these two records display a nonsignificant negative correlation (Table 1). Superimposed to this general trend, the ${ }^{230}$ Th-normalized Fe flux exhibits several increases at around 10.6-10.2, 8.9-8.2, 7.6-7, 6.2-5.3, 4.5-3.5, and 2.4-1.4 cal ka B.P. (Figure 2e).

[24] Values of the nitrogen stable isotope ratio of the bulk sediment $\left(\delta^{15} \mathrm{~N}_{\text {bulk }}\right)$ vary from 1.5 to $3 \%$. When inversed on its $y$ axis, the $\delta^{15} \mathrm{~N}_{\text {bulk }}$ record shows a similar trend than the setae diatom group record and the ${ }^{230}$ Th-normalized Fe flux record with heavier values between 11 and $5 \mathrm{cal} \mathrm{ka}$ B.P. and a steady trend since 5 cal ka B.P. toward lighter values (Figure 2f). Episodic decreases (lighter values) at around 10.6-10.2, 9.9-9.4, 8.7-8, 7.6-7, 6.5-6, 3-2.6 and $1.6-1 \mathrm{cal} \mathrm{ka}$ B.P. are superimposed on the general trend (Figure 2f). The $\delta^{15} \mathrm{~N}_{\text {bulk }}$ signal displays significant negative correlations with the setae diatom group and the ${ }^{230}$ Th-normalized Fe flux and a negative but nonsignificant correlation with the ${ }^{230}$ Th-normalized $\mathrm{N}_{\text {org }}$ flux (Table 1). Conversely, the $\delta^{15} \mathrm{~N}_{\text {bulk }}$ record is significantly correlated to records of the summer diatom group and the CRS relative abundances (Table 1 ).

[25] Modeled ice-free duration in months per year shows a long-term increase from 9 to $1.7 \mathrm{cal} \mathrm{ka} \mathrm{B.P.,} \mathrm{followed} \mathrm{by} \mathrm{a}$ slight decrease until 0.2 cal ka B.P. (Figure 2h). Model output indicates that the ice-free season was shorter during the Early Holocene (January-February) than during the Late Holocene (January-March at 1.7 cal ka B.P.).

\section{Discussion}

\subsection{Holocene Paleoproductivity}

[26] Records of ${ }^{230}$ Th-normalized fluxes of BSi, $\mathrm{C}_{\text {org }}$ and $\mathrm{N}_{\text {org }}$ present similar patterns during the Holocene (Figure 2a) as attested by the significant positive correlation coefficients between the three records (Table 1). The ${ }^{230}$ Th-normalized fluxes of $\mathrm{BSi}, \mathrm{C}_{\text {org }}$ and $\mathrm{N}_{\text {org }}$ in core MD03-2601 display significant changes in Holocene paleoproductivity. Carson [2009] compared ${ }^{230}$ Th-normalized BSi and $\mathrm{C}_{\text {org }}$ fluxes in core MD03-2601 to modern estimations of opal and organic carbon fluxes. This study demonstrated that these fluxes did not result from differential preservation at the sea sediment interface, therefore, representing an accurate reconstruction of past buried productivity.

[27] Paleoproductivity, and resultant organic matter sequestration in the DDUT area, during the Holocene show changes at two timescales. At plurimillennial timescale, the Hypsithermal 1 period, which was affected by the end of the deglaciation, is characterized by globally low paleoproductivity, whereas the Hypsithermal 2 period is marked by a long-term increase of organic matter burial. During the Neoglacial period, the organic matter sequestration in the DDUT remained high though decreasing toward modern time. The Neoglacial plurimillennial trend should however be taken with caution because it here covers only the 3.51 ka B.P. period and presents a strong millennial signature. Nonetheless, the Holocene can be coarsely divided with lower and higher biological pump efficiency before and after 5 cal ka B.P., respectively (Figure 2a).

[28] At the millennial timescale, 6 major events of higher organic burial have occurred at around 10.6-10.2, 8.7-8, $7.6-7,6.2-5.3,4.6-3.5$, and $2.4-1.4$ cal ka B.P. (Figure 2a). These productive events, referred as PE1 to PE6, are defined within the age model uncertainties. The amplitude and duration of PE increased along the Holocene until 3 cal ka B.P. and decreased since 3 cal ka B.P., in agreement with the plurimillennial pattern (Figure 2a).

\subsection{Paleoproductivity and Diatom Assemblages}

[29] In Adélie Land, diatoms are the dominant phytoplankton group in surfaces waters [Wright and van den Enden, 2000; Beans et al., 2008]. At the Holocene scale, diatoms have dominated the hemipelagic sedimentation as demonstrated by the good concordance between total diatom abundances and paleoproductivity proxies between 9 and 2.4 cal ka B.P. [Carson, 2009].

[30] The summer diatom group shows congruent variations with the three paleoproductivity records both at plurimillennial and millennial timescales though relative abundances of the summer diatom group slightly predate PE1 and are subdued during PE6 (Figures 2a and 2b and Table 1). The summer diatom assemblage in the CCSZ presents generally low growth rates, high degrees of silicification and high cellular content [Martin-Jézéquel et al., 2000; Menden-Deuer and Lessard, 2000; Kemp et al., 2006; Assmy et al., 2006; Armand et al., 2008]. High degree of silicification reduces dissolution and grazing pressure while promoting rapid export of $\mathrm{BSi}$ and organic matter to the seafloor [Smetacek et al., 2004]. The capacity of these diatom species to stock large amount of organic matter and efficiently export it to the seafloor explains the concomitant Holocene changes between the relative abundances of the summer diatom group and the paleoproductivity proxies observed here.

[31] In contrast, "bloomer" species such as Chaetoceros spp. are thought to add little to the preserved paleoproductivity signals. Indeed, relative abundances of Chaetoceros 
Hyalochaete spp. resting spores display opposite trends to the paleoproductivity proxies with significant negative correlation with the $\mathrm{N}_{\text {org }}$ flux record and almost significative negative correlations with $\mathrm{BSi}$ and $\mathrm{C}_{\text {org }}$ flux records (Figures $2 a-2 c$ and Table 1). CRS can achieve high relative abundances in surface water and be efficiently buried in sediment forasmuch as high sinking rates [Leventer, 1991] as observed during the Early Holocene (Figure 2c). However, the residual burial in term of BSi and organic material is low (Figures $2 \mathrm{a}-2 \mathrm{c}$ ) mainly because of their small size and low biogenic content [Armand et al., 2008].

[32] Our diatom results in core MD03-2601 demonstrate that periods of strong organic matter burial in the CCSZ do not result from rapid and intense blooms, but are generally due to the slow summer production of large and highly silicified diatoms. However, the amplitude of burial fluxes during PE6 are higher than the corresponding signal in the relative abundances of the summer diatom group (Figures $2 \mathrm{a}$ and $2 \mathrm{~b}$ ) and in total diatom absolute abundances [Carson, 2009]. This may indicate that the summer diatom community was not the only vector of the biogenic vertical fluxes to the seafloor during this period. Several processes, possibly acting together with diatoms, may explain PE6. First, high abundances of species of the setae diatom group can achieve great abundances in surface waters of the CCSZ [Leventer et al., 2002; Beans et al., 2008]. However, these species are generally scarce in the sediment because of their low export efficiency. Diatom species that possess setae and large spines are more easily dissolved because of their great buoyancy and high surface/volume ratio [Beucher et al., 2004; Ragueneau et al., 2006]. In core MD03-2601, the summed relative abundances of these species peak during PE2, PE3, PE4, PE5 and especially PE6 (Figure 2d) indicating that they may participate to biogenic silica and organic matter export when abundant. Second, high occurrence of other Antarctic siliceous phytoplankton groups such as parmales and sponge spicules may contribute to BSi export though they may little participate to $\mathrm{C}_{\text {org }}$ and $\mathrm{N}_{\text {org }}$ burial. Other siliceous organisms present low abundances in core MD03-2601, generally not in phase with PE. Third, other sources such as bacteria, broken diatoms and other phytoplankton, and fecal pellets can export $\mathrm{BSi}, \mathrm{C}_{\text {org }}$ and $\mathrm{N}_{\text {org }}$ [Krell et al., 2005]. These fractions are difficult to assess downcore.

[33] The efficiency of the biological pump, which has increased between 9 and 5 cal ka B.P. to reach highest Holocene levels between 5 and 1 cal ka B.P. for Corg and Norg and 6-2 cal ka B.P. for BSi at the plurimillennial timescale and during $\mathrm{PE}$ at millennial timescale, was clearly associated with greater export of large and heavily silicified diatoms thriving during ice-free summer season, except during PE6. Warmer temperatures and less icy environmental conditions promoting the summer species were prevailing during the 9-3.5 ka B.P. period [Crosta et al., 2005a, 2008]. It is therefore possible that the recent and future warming inducing longer sea ice-free season at high southern latitudes will be favorable to higher paleoproductivity and consequently more active biological pump. There is however a need to better understand what are the environmental factors controlling modern and past productivity.

\subsection{Factors Controlling Paleoproductivity}

[34] We now compared our results with a set of proxies that document the nutrient pool, the stratification and the duration of the growing season in order to identify the role of these controlling factors on past biological pump efficiency.

\subsubsection{Nutrient and Trace Metal Availability}

[35] Variations in macronutrient and micronutrient pools and utilization are here investigated from the records of the setae diatom group, the ${ }^{230}$ Th-normalized Fe flux and the $\delta^{15} \mathrm{~N}_{\text {bulk }}$, respectively. According to the Beans et al. [2008] study conducted in the Adélie Land region, the setae diatom group is associated to nutrient-rich and mixed surface waters. This is here supported at the Holocene scale by the significant anticorrelation between relative abundances of the setae group and of CRS. Chaetoceros resting spores are known to form in well-stratified surface waters that prevent nutrient refill [Leventer, 1991, 1992; Crosta et al., 1997; Leventer et al., 2002] (Table 1). The ${ }^{230}$ Th-normalized Fe flux here reconstructs Holocene changes of iron stocks in surface waters, and thus, more largely, of micronutrient availability. The $\delta^{15} \mathrm{~N}_{\text {bulk }}$ is considered as a proxy for relative nutrient utilization in nitrate replete environments whereby enriched $\delta^{15} \mathrm{~N}_{\text {bulk }}$ values indicate higher nitrate relative utilization [Altabet and Francois, 1994]. The nitrate relative utilization here represent a balance between nitrate supply via the MCDW upwelling and consumption by the phytoplankton.

[36] Records of the setae diatom group and ${ }^{230} \mathrm{Th}$ normalized Fe flux show significant inverse relationship with the $\delta^{15} \mathrm{~N}_{\text {bulk }}$ record, thus indicating less nitrate relative utilization under replete conditions (Table 1). Conversely, the $\delta^{15} \mathrm{~N}_{\text {bulk }}$ record shows significant and positive correlations with the summer diatom group and the CRS relative abundances (Table 1).

[37] At the plurimillennial timescale, both the macronutrient pool and the iron pool display lower levels prior to 5 cal ka B.P. and higher levels after 5 cal ka B.P. Low nutrient levels older than 5 cal ka B.P. are congruent to high nitrate relative utilization and lower paleoproductivity while high nutrient levels younger than 5 cal ka B.P. are concomitant to decreasing nitrate relative utilization and higher paleoproductivity (Figures 2a, 2d, 2e, and 2f).

[38] At the millennial timescale, macronutrient and trace metal availabilities in Adélie Land surface waters increased concomitantly during PE2, PE3, PE4 and PE6. In same time, nitrate relative utilization decreased (Figures 2a, 2d, $2 \mathrm{e}$, and 2f). During PE1, the iron pool increased and the nutrient relative utilization decreased, and the setae diatom group showed no significant changes. During PE5, both the macronutrient and iron pools increased but were not accompanied by significant change in the $\delta^{15} \mathrm{~N}_{\text {bulk }}$ (Figures $2 \mathrm{a}$, $2 \mathrm{~b}, 2 \mathrm{e}, 2 \mathrm{f}$, and $2 \mathrm{~g}$ ).

[39] The $\delta^{15} \mathrm{~N}_{\text {bulk }}$ signal follows the pattern of nutrient and micronutrient proxies, except during PE1, and is opposite to the paleoproductivity records. Statistically, the $\delta^{15} \mathrm{~N}_{\text {bulk }}$ signal presents a stronger correlation with the setae diatom group (Table 1), which is a proxy for the upwelling 
of MCDW. In core MD03-2601, the $\delta^{15} \mathrm{~N}_{\text {bulk }}$ signal appears, therefore, mainly controlled by changes in the nitrogen supply rather than in the nitrogen uptake by phytoplankton. The $\delta^{15} \mathrm{~N}_{\text {bulk }}$ signal along the setae group and the Fe flux records are coherent to depict an increase in macronutrient and micronutrient supply during periods of highest paleoproductivity, observed after $6-5$ cal ka B.P. and during PE. Higher nutrient supply sustained phytoplankton production by delaying the appearance of limiting conditions. Several studies in coastal Antarctic environments demonstrate that nutrients, and particularly iron, stimulate surface water productivity by accelerating the growth rate of small diatom species [Smetacek et al., 2004; Leventer et al., 2006; Timmermans et al., 2008]. In contrast in core MD032601, nutrient-rich periods congruent to higher paleoproductivity are associated with large diatom species having low growth rate. Thereby, other factors are certainly involved to explain the relationships between paleoproductivity, diatom assemblages and nutrient supply in the DDUT region during the Holocene.

\subsubsection{Water Column Stratification}

[40] Water column stratification is another key environmental factor for the biological pump efficiency because it determines phytoplankton community and, here, diatom specie assemblages. Different diatom species present different organic and silica contents along with different sinking rates, which in turn dictates the quality of the organic matter exported (e.g., new or recycled production, broken or intact phytoplanktonic cells) [Arrigo et al., 1999, 2008; Kemp et al., 2000, 2006; Wright and van den Enden, 2000]. In DDUT, we observe a decrease of the water column stratification over the course of the Holocene, demonstrated by the decrease of the CRS [Crosta et al., 2008] and the increase of the diatom setae group (Figure 2d). The inferred trend in surface water stratification is opposite to the longterm increase of Holocene paleoproductivity, at least until 3-4 cal ka B.P. (Figures 2a, 2c, and 2d). Since then, productivity started to decrease slightly while stratification continued to diminish at the same pacing. Similarly, at the millennial timescale, during PE, drops in CRS abundances are concomitant to peaks in the setae diatom group abundances (Figures 2c and 2d). Thereby, in Adélie Land, the periods of higher paleoproductivity at both plurimillennial and millennial timescales are associated to nutrient-rich and mixed surface waters.

[41] The two majors processes that control both stratification and nutrient supply in CCSZ are spring sea ice melting and upwelling of MCDW [Edwards and Sedwick, 2001; Sambrotto et al., 2003; Lannuzel et al., 2007], with opposite impacts on the water column stratification. Sea ice and ice melting release fresh, cold and nutrient-rich waters at the origin of a strong pycnocline that reduces the exchange with underlying waters. In contrast, upwelling of MCDW, which is promoted by winds [Toggweiler et al., 2006], mixes and renews the CCSZ water masses. The prevalence of mixed and nutrient-rich conditions during periods of higher paleoproductivity (e.g., Late Holocene and PE) could indicate a strengthening of the upwelling/ wind regime that recurrently destroyed the upper water column stratification induced by sea ice melting. More precisely, spring conditions, e.g., well-stratified water column with a well established pycnocline, were rapidly disappearing because of stronger winds, thus promoting the onset of summer conditions, e.g., deeper and less stable water column with a more permeable pycnocline, earlier in the season and extended later in the autumn. The early destruction (just after sea ice waning) of the upper water column stratification would reduce the development of small, high growth rate diatom species that are most competitive in well-stratified water column conditions [Leventer, 1991, 1992; Maddison et al., 2005, 2006; Stickley et al., 2005; Beans et al., 2008].

\subsubsection{Growing Season Duration}

[42] The length of the growing season or ice-free season strongly impacts the species composing diatom assemblages and therefore productivity and export/burial. In the CCSZ, the growing season duration is mainly controlled by the annual sea ice cycle, e.g., the timing of sea ice waning and waxing, which depends on several parameters such as temperature, wind, oceanic circulation, glacier.

[43] Our results (Figure 2b) suggested that the ice-free season increased along the Holocene since $3.5 \mathrm{cal}$ ka B.P. and then decreased as previously shown by Crosta et al. [2008]. These changes in sea ice duration are accompanied by a later sea ice melting in spring and later sea ice freezing autumn during the Neoglacial than the Hypsithermal period [Crosta et al., 2008; Pike et al., 2009]. Modeled ice-free season duration in DDUT increased from 9 cal ka B.P. to 1.7 cal ka B.P. and subsequently diminished (Figure 2i). The ice-free season is progressively extended on the autumn season with January-February ice-free conditions on the Early Holocene to January-March ice-free conditions on the Late Holocene (at 1.7 cal ka B.P.) (Figure 2i). At the Southern Ocean scale, the model reports similar increase of the ice-free season duration until 5 cal ka B.P., as a result of later sea ice melting in spring and later sea ice freezing in autumn [Renssen et al., 2005]. After 5 cal ka B.P., the model output for the Southern Ocean shows a shortening of the ice-free season by a later sea ice melting in spring and an earlier sea ice freezing in autumn [Renssen et al., 2005].

[44] Therefore up to 5 cal ka B.P., diatom records and model outputs support each other and demonstrate an increase of the ice-free season duration toward the autumn. After 5 cal ka B.P., some discrepancies appear between the different model outputs and the geological data, which are certainly link to local specificity such as the impact of glacier readvance on sea ice that have occurred at $3.5 \mathrm{cal} \mathrm{ka}$ B.P. [Denis et al., 2009] (Figure 2k). Thereby, we believe that in DDUT, longer ice-free conditions are maintained up to 3.5 cal ka B.P.

[45] The long-term variations in duration and timing of the ice-free season resulted from an increase of oceanic and atmospheric temperatures and wind strength combined to changes in the seasonality of local insolation at the precessional timescale [Renssen et al., 2005] (Figure 2h). These orbitally forced Holocene changes work in the same direction to provoke early waning and later waxing of sea ice up to $3.5-5$ cal ka B.P. though the modeled winter sea ice cover increases during the Holocene [Renssen et al., 2005; Denis et al., 2009]. The apparent paradox between winter 
and summer sea ice cover results from the increasing seasonality caused by the Holocene evolution of the precessional index (Figure 2h).

[46] The increased duration of ice-free conditions until 3.5 ka B.P. (Figure 2b) induced a progressive longer phytoplanktonic growing season favorable to the production of summer diatoms that have lower growth rates [MartinJézéquel et al., 2000; Kemp et al., 2006; Armand et al., 2008; Assmy et al., 2006]. A longer growing season is also suitable to the build up of more robust diatoms frustules by incorporation of more nutrients [Martin-Jézéquel et al., 2000], supported by concomitant higher nutrient supply. Larger and heavier silicified diatoms sink more rapidly and are more resistant to grazing pressure, which both contribute to an efficient drawdown of organic matter (Figures 2a and $2 b)$. Reduction of the ice-free season, and resulting phytoplankton growing season, since 3.5 cal ka B.P. led to less summer diatom production and decreasing of the paleoproductivity though it can be partly counterbalanced by auspicious nutrient conditions (Figures $2 \mathrm{a}, 2 \mathrm{~b}, 2 \mathrm{~d}, 2 \mathrm{e}$, and 2f). At plurimillennial timescales, the length of the phytoplanktonic growing season, which is closely linked to sea ice dynamics, appears, thus, a key factor in determining the specific composition of the diatom assemblage and the intensity of the PP.

[47] At millennial timescale, PE1, PE3 and PE5 occurred during warmer Holocene phases in East Antarctica, which could be favorable to extended ice-free season (Figure $2 \mathrm{j}$ [Masson et al., 2000]). In contrast, PE4 spanned over a warm and a cold phase, which is associated to glacier and sea ice advance (Figures 2j and 2k [Masson et al., 2000; Denis et al., 2009]). PE2 and PE6 occurred during cold phases and glacier/sea ice advances (Figures $2 \mathrm{j}$ and $2 \mathrm{k}$ [Masson et al., 2000; Denis et al., 2009]). At face value, no general pattern between climate/sea ice dynamic and millennial-scale PE is discernable in the DDUT region. All PE show an increase in the summer diatom group abundances (Figure 2b), which argue for a longer summer season during millennial events. A longer growing season during cold phases may be related to the mechanical breakup of the sea ice by more intense winds (Figure $2 \mathrm{f}$ ).

[48] Lower paleoproductivity are reported during periods of massive freshwater input at $\sim 11$ and $\sim 9.5 \mathrm{cal} \mathrm{ka} \mathrm{B.P.} \mathrm{and}$ of major glacier/sea ice readvances at $\sim 7.7$ and $\sim 3$ cal ka B.P. (Figure 2k [Denis et al., 2009]). Therefore, the local behavior of glacier can strongly modulate the growing season duration through its impact on the sea ice cycle, on the surface water stratification and resulting upwelling.

\subsection{Paleoclimatic Implications}

[49] Climate-forced changes in nutrient supply, stratification and growing season duration determined the type and amount of surface water PP at both plurimillennial and millennial timescales. Periods of enhanced wind and upwelling associated to longer ice-free season led to nutrientrich mixed surface waters that supported high surface and exported/buried PP as a result of the development of larger and heavier silicified diatoms. In contrast, periods of reduced wind and upwelling activity associated to shorter icefree season led to nutrient depleted and well-stratified surface waters that supported low surface PP and subsequently limited organic matter burial.

[50] We highlight here the positive effects of stronger winds and enhanced seasonal sea ice cycle on the Si, C and $\mathrm{N}$ biological pump in the CCSZ off Adélie Land. A plurimillennial increase of the upwelling/wind intensity during the Holocene is consistent with several geological and model studies that reported/suggested a long-term increase of the wind intensity over the Holocene in East Antarctica [Steig et al., 2000; van Ommen et al., 2004] and high southern latitudes [Vimeux et al., 2001; Renssen et al., 2005]. Accordingly, long-term changes in ice-free season duration, recorded in Adélie Land area, may represent a Holocene Antarctic-wide feature because Holocene patterns in winds, ocean and atmosphere temperatures are similar around AA [Renssen et al., 2005]. Therefore, plurimillennial changes in the CCSZ would be dictated by the Milankovitch precessional cycle with feedback from the regional cryosphere.

[51] Much less is known about forcing factors of the Antarctic PP at the millennial scale. Our results demonstrate that wind intensity and sea ice dynamic are the main controlling factors with strong feedback from the regional glaciers. Indeed, though homogenous wind variations over the Southern Ocean and CCSZ are expected (Figure 2g [Mayewski and Maasch, 2006; Mayewski et al., 2009]), local ice cap morphology and glacier dynamic [Ingólfsson et al., 1998; Denis et al., 2009] strongly modulate local winds, sea ice cycle and water column structure. As a result, millennial productivity variations may be decoupled from climate changes (Figures $2 \mathrm{a}-2 \mathrm{j}$ ). It is also worth exploring whether high-latitude climate modes, such as the Antarctic Dipole, characterized by an out-of-phase relationship between sea ice and surface temperature anomalies in the South Pacific and South Atlantic [Yuan, 2004] prevailed during the Holocene at the millennial scale and could affect organic matter sequestration. Finally, we note that PE2, PE4, PE5 and the major glacier readvance at $3.5 \mathrm{cal} \mathrm{ka}$ B.P. recorded in core MD03-2601 coincide with the worldwide rapid climatic changes (RCC) reported in the 50paleorecord study of Mayewski et al. [2004] (Figure 21). Therefore, millennial climatic variations recorded in Adélie Land, and possibly in Antarctic CCSZ with close environmental conditions and phytoplanktonic successions, could be part of a more general Holocene pattern.

[52] Predictions of future climate suggest enhanced Southern Ocean winds, enhanced upwelling of nutrient-rich waters [Toggweiler et al., 2006; Russell et al., 2006], retreat of sea ice extent and longer ice-free season [Goosse and Renssen, 2001; Lefebvre and Goosse, 2008]. In that perspective, our results would emphasize an increase of the carbon biological pump in the CCSZ, which would implicate a slight negative feedback on climate warming as suggested by Arrigo and Thomas [2004], Tortell et al. [2008] and Arrigo et al. [2008]. In addition, the decrease in dust-bearing iron to Antarctica and surrounding waters [Kattenberg et al., 1996; Sarmiento et al., 1998], which represent a minor source to coastal Antarctic waters, will have a limited impact on the phytoplankton productivity of 
the CCSZ [Edwards and Sedwick, 2001; Lannuzel et al., 2007].

\section{Conclusion}

[53] This study provides the first ${ }^{230}$ Th-normalized highresolution Holocene record of primary productivity (PP) from the Antarctic Continental Shelf (CCSZ), therefore giving unprecedented insights on the biological pump of the Adélie Land CCSZ in response to climatic changes at both plurimillennial and millennial timescales. A long-term increase of PP since $9 \mathrm{cal} \mathrm{ka}$ B.P. to reach highest values between 5 and $1 \mathrm{cal}$ ka B.P. for $\mathrm{C}_{\text {org }}$ and $\mathrm{N}_{\text {org }}$ and 6-2 for BSi and six events of higher paleoproductivity at 10.6$10.2,8.7-8,7.6-7,6.2-5.3,4.6-3.5$, and $2.4-1.4$ cal ka B.P. are evidenced along the Holocene. More efficient biological pump at these two timescales was mainly promoted by higher PP and the development of large and heavily silicified summer diatoms, which are associated to higher nutrient supply, reduced stratification and longer ice- free season. These environmental conditions were mainly controlled at these timescales by the wind regime and the sea ice cycle as well as the dynamic of adjacent glaciers. Our results, emphasizing enhanced PP during warmer and windier Holocene periods, suggest stronger $\mathrm{CO}_{2}$ biological pump in the future though the relationships between the biological pump and the environmental conditions in the CCSZ were not straightforward throughout the Holocene. In this vein, additional studies are necessary to constrain the influence of seeding, aggregate formation, bacterial and grazing pressure in relation to the sea ice cycle.

[54] Acknowledgments. We personally thank people from the Images X (CADO) cruise and from the NSF-funded NBP0101 cruise for data and suggestions concerning the Dumont d'Urville Trough. Financial support for this study was provided by TARDHOL and JC ARTTE projects through the national LEFE-EVE and ACI programs (INSU-CNRS), with the logistic support of the French Institut Paul Emile Victor and the International Marine Past Global Change Study. This is EPOC contribution 1750 .

\section{References}

Abdi, H. (2007), The Bonferonni and Šidák corrections for multiple comparisons, in Encyclopedia of Measurement and Statistics, edited by N. J. Salkind, pp. 103-107, SAGE, Thousand Oaks, Calif.

Adolphs, U., and G. Wendler (1995), A pilot study on the interactions between katabatic winds and polynyas at the Adélie Coast, eastern Antarctica, Antarct. Sci., 7(3), 307-314, doi:10.1017/S0954102095000423.

Altabet, M. A., and R. Francois (1994), Sedimentary nitrogen isotopic ratio as a recorder for surface ocean nitrate utilization, Global Biogeochem. Cycles, 8(1), 103-116, doi:10.1029/93GB03396.

Armand, L. K., X. Crosta, O. Romera, and J.-J. Pichon (2005), The biogeography of major diatom taxa in Southern Ocean sediments: 1 Sea ice related species, Palaeogeogr. Palaeoclimatol. Palaeoecol., 223, 93-126, doi:10.1016/j.palaeo.2005.02.015.

Armand, L. K., V. Cornet-Barthaux, J. Mosseri, and B. Quéguiner (2008), Late summer diatom biomass and community structure on and around the naturally iron-fertilised Kerguelen Plateau in the Southern Ocean, Deep Sea Res., Part II, 55(5-7), 653-676, doi:10.1016 j.dsr2.2007.12.031.

Arrigo, K. R., and D. N. Thomas (2004), Large scale importance of sea ice biology in the Southern Ocean, Antarct. Sci., 16(4), $471-$ 486, doi:10.1017/S0954102004002263.

Arrigo, K. R., and G. L. van Dijken (2003), Phytoplankton dynamics within 37 Antarctic coastal polynya systems, J. Geophys. Res. 108(C8), 3271, doi:10.1029/2002JC001739.

Arrigo, K. R., D. H. Robinson, D. L. Worthen, R. B. Dunbar, G. R. DiTullio, M. V. Woert, and M. P. Lizotte (1999), Phytoplankton community structure and the drawdown of nutrients and $\mathrm{CO}_{2}$ in the Southern Ocean Science, 283, 365-367, doi:10.1126/ science.283.5400.365.

Arrigo, K. R., D. L. Worthen, and D. H. Robinson (2003), A coupled ocean-ecosystem model of the Ross Sea: 2. Iron regulation of phytoplankton taxonomic variability and primary production, J. Geophys. Res., 108(C7), 3231, doi:10.1029/2001JC000856.
Arrigo, K. R., G. L. van Dijken, and S. Bushinsky (2008), Primary production in the Southern Ocean, 1997-2006, J. Geophys. Res., 113, C08004, doi:10.1029/ 2007JC004551.

Assmy, P., J. Henjes, V. Smetacek, and M. Montresor (2006), Auxospore formation by the silica-sinking, oceanic diatom Fragilariopsis kerguelensis (Bacillariophyceae), J. Phycol., 42, 1002-1006, doi:10.1111/ j.1529-8817.2006.00260.x.

Beans, C., J. H. Hecq, P. Koubbi, C. Vallet, S. Wright, and A. Goffart (2008), A study of the diatom-dominated microplankton summer assemblages in coastal waters from Terre Adélie to the Mertz Glacier, East Antarctica $\left(139^{\circ} \mathrm{E}-145^{\circ} \mathrm{E}\right)$, Polar Biol., 31(9), $1101-$ 1117, doi:10.1007/s00300-008-0452-x.

Berger, A., and M. F. Loutre (1991), Insolation values for the climate of the last 10 million years, Ouat. Sci. Rev., 10, 297-317, doi:10.1016/0277-3791(91)90033-Q.

Berger, W. H., and G. Wefer (1990), Export production: Seasonality and intermittency, and paleoceanographic implications, Palaeogeogr Palaeoclimatol. Palaeoecol., 89, 245-254, doi:10.1016/0031-0182(90)90065-F.

Beucher, C., P. Tréguer, A.-M. Hapette, R. Corvaisier, N. Metzl, and J.-J. Pichon (2004), Intense summer Si-recycling in the surface Southern Ocean, Geophys. Res. Lett., 31 , L09305, doi:10.1029/2003GL018998.

Bindoff, N. L., S. R. Rintoul, and R. Massom (2000a), Bottom water formation and polynyas in Adélie Land, Antarctica, Pap. Proc. R. Soc. Tasmania, 133(3), 51-57.

Bindoff, N. L., M. A. Rosenberg, and M. J. Warner (2000b), On the circulation and water masses over the Antarctic continental slope and rise between 80 and $150^{\circ} \mathrm{E}$, Deep Sea Res., Part II, 47(12-13), 2299-2326, doi:10.1016/S0967-0645(00)00038-2.

Buesseler, K. O. (1998), The decoupling of production and particulate export in the surface ocean, Global Biogeochem. Cycles, 12(2), 297-310, doi:10.1029/97GB03366.

Carson, D. (2009), Biogeochemical controls on productivity and particle flux in the coastal Antarctic sea ice environment, $\mathrm{Ph}$. D thesis,
168 pp., Univ. of Edinburgh, Edinburgh, U. K.

Cassar, N., M. L. Bender, B. A. Barnett, S. Fan, W. J. Moxim, H. Levy II, and B. Tilbrook (2007), The Southern Ocean biological response to aeolian iron deposition Science, 317, 1067-1070, doi:10.1126/ science. 1144602

Coale, K. H., R. M. Gordon, and X. Wang (2005), The distribution and behavior of dissolved and particulate iron and zinc in the Ross Sea and Antarctic Circumpolar Current along $170^{\circ} \mathrm{W}$, Deep Sea Res., Part I, 52(2), 295-318, doi:10.1016/j.dsr.2004.09.008.

Collier, R., J. Dymond, S. Honjo, S. Manganini, R. Francois, and R. Dunbar (2000), The vertical flux of biogenic and lithogenic material in the Ross Sea: Moored sediment trap observations 1996-1998, Deep Sea Res., Part II, 47(15-16), 3491-3520, doi:10.1016/S09670645(00)00076-X.

Crosta, X., J.-J. Pichon, and M. Labracherie (1997), Distribution of Chaetoceros resting spores in modern peri-Antarctic sediments, Mar. Micropaleontol., 29, 283-299, doi:10.1016/S0377-8398(96)00033-3.

Crosta, X., A. Sturm, L. Armand, and J.-J Pichon (2004), Late Quaternary sea ice history in the Indian sector of the Southern Ocean as recorded by diatom assemblages, Mar. Micropaleontol., 50, 209-223, doi:10.1016/S0377. 8398(03)00072-0.

Crosta, X., J. Crespin, I. Billy, and O. Ther (2005a), Major factors controlling Holocene $\delta^{13} \mathrm{C}_{\mathrm{org}}$ changes in a seasonal sea-ice environment, Adélie Land, East Antarctica, Global Biogeochem. Cycles, 19, GB4029, doi:10.1029/2004GB002426.

Crosta, X., O. Romero, L. K. Armand, and J.-J. Pichon (2005b), The biogeography of major diatom taxa in Southern Ocean sediments: 2. Open ocean related species, Palaeogeogr. $\mathrm{Pa}$ laeoclimatol. Palaeoecol., 223, 66-92, doi:10.1016/j.palaeo.2005.03.028.

Crosta, X., D. Denis, and O. Ther (2008) Sea ice seasonality during the Holocene, Adélie Land, East Antarctica, Mar. Micropaleontol., 66, 222-232, doi:10.1016/j marmicro.2007.10.001. 
Denis, D., X. Crosta, S. Zaragosi, O. Romero, B. Martin, and V. Mas (2006), Seasonal and subseasonal climate changes recorded in laminated diatom ooze sediments, Adélie Land, East Antarctica, Holocene, 16(8), 1137 1147, doi:10.1177/0959683606069414

Denis, D., et al. (2009), Holocene glacier and deep water dynamics, Adélie Land region, East Antarctica, Ouat. Sci. Rev., 28, 1291 1303, doi:10.1016/j.quascirev.2008.12.024

Edwards, R., and P. Sedwick (2001), Iron in East Antarctic snow: Implications for atmospheric iron deposition and algal production in Antarctic waters, Geophys. Res. Lett., 28(20), 3907-3910, doi:10.1029/2001GL012867.

Fitton, J. G., A. D. Saunders, L. M. Larsen, B. S. Hardarson, and M. J. Norry (1998), Volcanic rocks from the southeast Greenland margin at $63^{\circ} \mathrm{N}$ : Composition, petrogenesis, and mantle sources, Proc. Ocean Drill. Program Sci. Results, 152(3-4), 331-350.

Francois, R., M. Frank, M. M. Rutgers van der Loeff, and M. P. Bacon (2004), ${ }^{230}$ Th normalization: An essential tool for interpreting sedimentary fluxes during the late Quaternary, Paleoceanography, 19, PA1018, doi:10.1029/ 2003PA000939

Goosse, H., and H. Renssen (2001), A twophase response of the Southern Ocean to an increase in greenhouse gas concentrations, Geophys. Res. Lett., 28(18), 3469-3472, doi:10.1029/2001GL013525.

Harris, P. T., and R. J. Beaman (2003), Processes controlling the formation of the Mertz Drift, George Vth continental shelf, East Antarctica: Evidence from $3.5 \mathrm{kHz}$ sub-bottom profiling and sediment cores, Deep Sea Res., Part II, 50(8-9), 1463-1480, doi:10.1016/S09670645(03)00070-5

Hughen, K. A., et al. (2004), Marine04 marine radiocarbon age calibration, $0-26 \mathrm{cal} \mathrm{kyr} \mathrm{BP}$ Radiocarbon, 46, 1059-1086.

Ingólfsson, O., et al. (1998), Antarctic glacial history since the Last Glacial Maximum: An overview of the record on land, Antarct. Sci., 10(3), 326-344, doi:10.1017/ S095410209800039X

Kattenberg, A., F. Giorgi, H. Grassl, G. A. Meehl, J. F. B. Mitchell, R. J. Stouffer, T. Tokioka, A. J. Weaver, and T. M. L. Wigley (1996), Climate models-Projection of future climate, in Climate Change 1995 The Science of Climate Change: Contribution of Working Group I to the Second Assessment Report of the Intergovernmental Panel on Climate Change, edited by J. T. Houghton et al., pp. 285-357, Cambridge Univ. Press, New York

Kemp, A. E. S., J. Pike, R. B. Pearce, and C. B. Lange (2000), The "fall dump"-A new perspective on the role of a "shade flora" in the annual cycle of diatom production and export flux, Deep Sea Res., Part II, 47(9-11), 21292154, doi:10.1016/S0967-0645(00)00019-9.

Kemp, A. E. S., R. B. Pearce, I. Grigorov, J. Rance, C. B. Lange, P. Quilty, and I. Salte (2006), Production of giant marine diatoms and their export at oceanic frontal zones: Implications for $\mathrm{Si}$ and $\mathrm{C}$ flux from stratified oceans, Global Biogeochem. Cycles, 20 GB4S04, doi:10.1029/2006GB002698.

Krell, A., S. B. Schnack-Schiel, D. N. Thomas, G. Kattner, W. Zipan, and G. S. Dieckman (2005), Phytoplankton dynamics in relation to hydrography, nutrients and zooplankton at the onset of sea ice formation in the eastern Weddell Sea (Antarctica), Polar Biol., 28(9), 700 713, doi:10.1007/s00300-005-0733-6.
Lannuzel, D., V. Schoemann, J. de Jong, J.-L. Tison, and L. Chou (2007), Distribution and biogeochemical behaviour of iron in the East Antarctic sea ice, Mar. Chem., 106(1-2), 18 32, doi:10.1016/j.marchem.2006.06.010.

Laws, R. A. (1983), Preparing strewn slides for quantitative microscopical analysis: A test using calibrated microspheres, Mar. Micropaleontol., 24, 60-65.

Lefebvre, W., and H. Goosse (2008), An analysis of the atmospheric processes driving the large-scale winter sea ice variability in the Southern Ocean, J. Geophys. Res., 113, C02004, doi:10.1029/2006JC004032.

Leventer, A. (1991), Sediment trap diatom assemblages from the northern Antarctic Peninsula region, Deep Sea Res., Part A, 38, 1127 1143, doi:10.1016/0198-0149(91)90099-2.

Leventer, A. (1992), Modern distribution of diatoms in sediments from the George V Coast, Antarctica, Mar. Micropaleontol., 19, 315332, doi:10.1016/0377-8398(92)90036-J.

Leventer, A., E. Domack, A. Barkoukis, B. McAndrews, and J. Murray (2002), Laminations from the Palmer Deep: A diatom-based interpretation, Paleoceanography, 17(3), 8002, doi:10.1029/2001PA000624.

Leventer, A., E. Domack, R. Dunbar, J. Pike, C. Stickley, E. Maddison, S. Brachfeld, P. Manley, and C. McClennen (2006), East Antarctic margin marine sediment record of deglaciation, GSA Today, 16, doi:10.1130/ GSAT01612A.1.

Longhurst, A. R., and W. G. Harrison (1989), The biological pump: Profiles of plankton production and consumption in the upper ocean Prog. Oceanogr., 22(1), 47-123, doi:10.1016/ 0079-6611(89)90010-4.

Maddison, E. J., J. Pike, A. Leventer, and E. W. Domack (2005), Deglacial seasonal and subseasonal diatom record from Palmer Deep, Antarctica, J. Quat. Sci., 20(5), 435-446, doi:10.1002/jqs.947.

Maddison, E. J., J. Pike, A. Leventer, R. Dunbar, S. Brachfeld, E. W. Domack, P. Manley, an C. McClennen (2006), Post-glacial seasonal diatom record of the Mertz Glacier polynya, East Antarctica, Mar. Micropaleontol., 60, 66-88, doi:10.1016/j.marmicro.2006.03.001.

Martin-Jézéquel, V., M. Hildebrand, and M. A. Brzezinski (2000), Silicon metabolism in diatoms: Implications for growth, J. Phycol., 36, 821-840, doi:10.1046/j.1529-8817.2000 00019.x

Massom, R. A., P. T. Harris, K. J. Michael, and M. J. Potter (1998), The distribution and formative processes of latent-heat polynyas in East Antarctica, Ann. Glaciol., 27, 420-426.

Masson, V., et al. (2000), Holocene climate variability in Antarctica based on 11 ice-core isotopic records, Quat. Res., 54, 348-358, doi:10.1006/qres.2000.2172.

Mayewski, P. A., and K. A. Maasch (2006), Recent warming inconsistent with natural association between temperature and atmospheric circulation over the last 2000 years, Clim. Past Discuss., 2(3), 327-355.

Mayewski, P. A., et al. (2004), Holocene climate variability, Quat. Res., 62, 243-255, doi:10.1016/j.yqres.2004.07.001.

Mayewski, P. A., et al. (2009), State of the Antarctic and Southern Ocean climate system, Rev. Geophys., 47, RG1003, doi:10.1029 2007RG000231.

Menden-Deuer, S., and E. J. Lessard (2000), Carbon to volume relationships for dinoflagellates, diatoms, and other protist plankton, Limnol. Oceanogr., 45(3), 569-579.
Nelson, D. M., P. Tréguer, M. A. Brzezinski, A. Leynaert, and B. Quéguiner (1995), Production and dissolution of biogenic silica in he ocean: Revised global estimates, comparison with regional data and relationship to biogenic sedimentation, Global Biogeochem. Cycles, 9(3), 359-372, doi:10.1029/ $95 \mathrm{~GB} 01070$

Nelson, D. M., D. J. DeMaster, R. B. Dunbar, and W. O. Smith Jr. (1996), Cycling of organic carbon and biogenic silica in the Southern Ocean: Estimates of water-column and sedimentary fluxes on the Ross Sea continental shelf, J. Geophys. Res., 101(C8), 18,51918,532, doi:10.1029/96JC01573.

Périard, C., and P. Pettré (1993), Some aspects of the climatology of Dumont d'Irville, Adélie Land, Antarctica, Int. J. Climatol., 13(3), 313-328, doi:10.1002/joc.3370130307.

Pike, J., X. Crosta, E. J. Maddison, C. E. Stickley, D. Denis, L. Barbara, H. Renssen, and A. Leventer (2009), Observations on the relationship between the Antarctic coastal diatoms Thalassiosira antarctica Comber and Porosira glacialis (Grunow) Jørgensen and sea ice concentrations during the late Quaternary, Mar. Micropaleontol., in press.

Ragueneau, O., S. Schultes, K. Bidle, P. Claquin, and B. Moriceau (2006), Si and C interactions in the world ocean: Importance of ecological processes and implications for the role of diatoms in the biological pump, Global Biogeochem. Cycles, 20, GB4S02, doi:10.1029/2006GB002688.

Renssen, H., H. Goosse, T. Fichefet, V. A Massom-Delmotte, and N. Koç (2005), Holocene climate evolution in the high-latitude Southern Hemisphere simulated by a coupled atmosphere-sea-ice-ocean-vegetation model, Holocene, 15(7), 951-964, doi:10.1191/0959683605hl869ra.

Rintoul, S. R. (1998), On the origins and influence of Adélie Land bottom water, in Ocean Ice, and Atmosphere: Interactions at the Antarctic Continental Margin, Antarct. Res. Ser. vol. 75, edited by S. S. Jacobs and R. F. Weiss, pp. 151-171, AGU, Washington, D. C.

Russell, J. L., K. W. Dixon, A. Gnanadesikan, R. J. Stouffer, and J. R. Toggweiler (2006), The Southern Hemisphere westerlies in a warming world: Propping open the door to the deep ocean, J. Clim., 19(24), 6382 6390, doi:10.1175/JCLI3984.1.

Sambrotto, R. N., A. Matsuda, R. Vaillancourt, M. Brown, C. Langdon, S. S. Jacobs, and C. Measures (2003), Summer plankton production and nutrient consumption patterns in the Mertz Glacier region of East Antarctica, Deep Sea Res., Part II, 50(8-9), 1393 1414, doi:10.1016/S0967-0645(03)00076-6.

Sarmiento, J. L., T. M. C. Hughes, R. J. Stouffer, and S. Manabe (1998), Simulated response of the ocean carbon cycle to anthropogenic climate warming, Nature, 393, 245-249, doi:10.1038/30455.

Schrader, H. J., and R. Gersonde (1978), Diatoms and silicoflagellates, in Micropaleontological Counting Methods and Techniques: An Exercise on an Eight Meters Section of the Lower Pliocene of Capo Rossello, Sicily, edited by W. J. Zachariasse et al., Utrecht Micropaleontol. Bull., 17, 129-176.

Schweitzer, P. N. (1995), Monthly average polar sea-ice concentration, U.S. Geol. Surv. Digital Data, 27

Sedwick, P. N., G. R. DiTullio, and D. J. Mackey (2000), Iron and manganese in the Ross Sea, Antarctica: Seasonal iron limitation 
in Antarctic shelf waters, J. Geophys. Res. 105(C5), 11,321-11,336, doi:10.1029/ 2000 JC000256.

Smetacek, V., and S. Nicol (2005), Polar ocean ecosystems in a changing world, Nature, 437 362-368, doi:10.1038/nature04161.

Smetacek, V., P. Assmy, and J. Henjes (2004), The role of grazing in structuring Southern Ocean pelagic ecosystems and biogeochemical cycles, Antarct. Sci., 16(4), 541-558, doi:10.1017/S0954102004002317.

Smith, W. O., Jr., and L. I. Gordon (1997), Hyperproductivity of the Ross Sea (Antarctica) polynya during austral spring, Geophys. Res. Lett., 24(3), 233-236, doi:10.1029 96GL03926.

Smith, W. O., Jr., and D. M. Nelson (1985), Phytoplankton biomass near a receding ice-edge in the Ross Sea, in Antarctic Nutrient Cycles and Food Webs, edited by W. R. Siegfried, P. R. Condy, and R. M. Laws, pp. 70-77, Springer, Berlin.

Steig, E. J., D. L. Morse, E. D. Waddington, M. Stuiver, P. M. Grootes, P. A. Mayewski, M. S. Twickler, and S. I. Whitlow (2000), Wisonsinan and Holocene climate history from an ice core at Taylor Dome, western Ross embayment, Antarctica, Geogr. Ann., Ser. A, $82(2-3), 213-235$, doi:10.1111/j.04353676.2000.00122.x

Stickley, C. E., J. Pike, A. Leventer, R. Dunbar, E. W. Domack, S. Brachfeld, P. Manley, and C. McClennen (2005), Deglacial ocean and climate seasonality in laminated diatom sediments, Mac.Robertson Shelf, Antarctica, $\mathrm{Pa}$ laeogeogr. Palaeoclimatol. Palaeoecol., 227, 290-310, doi:10.1016/j.palaeo.2005.05.021.
Strutton, P. G., F. B Griffiths, R. L. Waters, S. W. Wright, and N. L. Bindoff (2000), Primary productivity off the coast of East Antarctica $\left(80-150^{\circ} \mathrm{E}\right)$ : January to March 1996 , Deep Sea Res., Part II, 47(12-13), 2327 2362, doi:10.1016/S0967-0645(00)00028-X.

Timmermans, K. R., M. J. W. Veldhuis, P. Laan, and C. P. D. Brussaard (2008), Probing natura iron fertilization near the Kerguelen (Southern Ocean) using natural phytoplankton assemblages and diatom cultures, Deep Sea Res. Part II, 55(5-7), 693-705, doi:10.1016/ j.dsr2.2007.12.008.

Toggweiler, J. R., J. L. Russell, and S. R. Carson (2006), Midlatitude westerlies, atmospheric $\mathrm{CO}_{2}$, and climate change during the ice ages, Paleoceanography, 21, PA2005, doi:10.1029/2005PA001154.

Tortell, P. D., C. D. Payne, Y. Li, S. Trimborn, B. Rost, W. O. Smith, C. Riesselman, R. B Dunbar, P. Sedwick, and G. R. DiTullio (2008), $\mathrm{CO}_{2}$ sensitivity of Southern Ocean phytoplankton, Geophys. Res. Lett., 35 , L04605, doi:10.1029/2007GL032583.

van Ommen, T. D., V. I. Morgan, and M. A. J. Curran (2004), Deglacial and Holocene changes in accumulation at Law Dome, Ann. Glaciol., 39, 359-365, doi:10.3189 172756404781814221.

Vimeux, F., V. Masson, J. Jouzel, J. R. Petit, E. J. Steig, M. Stievenard, R. Vaikmae, and J. W. C. White (2001), Holocene hydrological cycle changes in the Southern Hemisphere documented in East Antarctic deuterium excess records, Clim. Dyn., 17, 503-513, doi:10.1007/ PL00007928.
Williams, G. D., and N. L. Bindoff (2003), Wintertime oceanography of the Adélie Depression, Deep Sea Res., Part II, 50(8-9), 1373 - 1392 , doi:10.1016/S09670645(03)00074-2.

Wright, S. W., and R. L. van den Enden (2000), Phytoplankton community structure and stocks in the East Antarctic marginal ice zone (BROKE survey, January-March 1996) determined by CHEMTAX analysis of HPLC pigment signatures, Deep Sea Res., Part II, 47(12-13), 2363-2400, doi:10.1016/S09670645(00)00029-1.

Yuan, X. (2004), ENSO-related impacts on Antarctic sea ice: A synthesis of phenomenon and mechanisms, Antarct. Sci., 16(4), 415-425, doi:10.1017/S0954102004002238

I. Billy, X Crosta, D. Denis, J. Giraudeau, S. Schmidt, and O. Ther, EPOC, UMR 5805, CNRS, Université Bordeaux 1, Avenue des Facultés, F-33405 Talence, Cedex, France. (delphine.den@voila.fr)

D. S. Carson and R. S. Ganeshram, Grant Institute, School of GeoSciences, University of Edinburgh, West Mains Road, Edinburgh EH9 3JW, UK.

J. Crespin, CEREGE, UMR 6635, CNRS, Europôle de 1'Arbois, F-13545 Aix-enProvence, Cedex 4, France.

H. Renssen, Faculty of Earth and Life Sciences, Vrije Universiteit Amsterdam, De Boelelaan 1085, NL-1081 HV Amsterdam, Netherlands. 